\title{
Allocation of risk and benefits—distributional justices in mountain hazard management
}

\author{
${\text { Thomas } \text { Thaler }^{1} \text { (I) } \cdot \text { Andreas Zischg }}^{2,3} \cdot{\text { Margreth } \text { Keiler }^{2,4} \cdot \text { Sven Fuchs }}^{1}$
}

Received: 22 November 2016 / Accepted: 22 September 2017 /Published online: 6 December 2017

(C) The Author(s) 2017. This article is an open access publication, corrected publication [January/2018]

\begin{abstract}
As financing protection against mountain hazards becomes increasingly challenging and therefore investments have to be prioritized, dilemmas of justice emerge: some local governments and individuals benefit from natural hazard protection schemes, whereas others loose. Decisions on whom to protect often caused contradicting concepts of political understanding, which differ in interpretations of fair resource allocation and distribution. This paper analyses the impact of different philosophical schools of social justice on mountain hazard management in Austria. We used data from a spatially explicit, object-based assessment of elements at risk and compared potential distributional effects of three political jurisdictions. We found that-depending on the respective political direction-various local governments gain and others loose within the actual distributional system of mitigation strategies. The implementation of a utilitarian policy approach would cause that high income communities in hazard-prone areas would mainly benefit. Consequently, this policy direction would encourage the public administration to ignore their own failure in the past natural hazards management and
\end{abstract}

Electronic supplementary material The online version of this article (https://doi.org/10.1007/s10113-017-1229-y) contains supplementary material, which is available to authorized users.

Thomas Thaler

thomas.thaler@boku.ac.at

1 Institute of Mountain Risk Engineering, University of Natural Resources and Life Sciences, Vienna, Austria

2 Mobiliar Laboratory for Natural Risks, Oeschger Centre for Climate Change Research, Institute of Geography, University of Bern, Bern, Switzerland

3 School of Geographical Sciences, University of Bristol, Bristol, UK

4 Institute of Geography, University of Bern, Bern, Switzerland prevention. On the other hand, following a Rawlsians approach mainly peripheral communities would gain from new policy direction who often show besides natural hazards problem mainly large socio-economic challenges. Finally, the most radical change would include the implementation of a liberalism policy, whereabouts the state only provides hazard information, but no further mitigation measures. These findings highlight the distributional consequences of future mountain hazard management strategies and point to the crucial selection of policy direction in navigating the selection of various adaptation schemes.

Keywords Social justice $\cdot$ Political economy $\cdot$ Risk reduction $\cdot$ Distributional consequences $\cdot$ Mountain hazards

\section{Introduction}

Since the beginning of 2000 s, the Austrian natural hazard funding policy is following a mixture of egalitarianism and utilitarianism social justices' direction (see also Thaler and Hartmann 2016). The national government introduced to prioritise the investment based on cost-benefit analysis, where the highest benefit-cost ratio gets implemented first (Sinabell and Url 2007; BMLFUW 2009). One reason for this result is that the overall budget and the resource distribution over the federal states is mainly disaster-driven (Thaler 2014), which means that after major strikes investments for mitigation and adaptation are repeatedly shifted towards these federal states (Raschky and Weck-Hannemann 2007). However, the allocation of flood protection measures is equally distributed in terms of protection level and also in terms of funding between nine different federal states. However, several natural hazard events, such as those that occurred in 2002, 2005, and 2013 in Austria, caused high damages for the environment and 
humanity, and losses for the economy (Habersack et al. 2004, 2009; Blöschl et al. 2013). This has focused the attention of policy makers and other stakeholders of how to approach the topic of natural hazard protection, which is that not everyone is threatened equally by hazard events. This has led to an increasing discussion on changes beyond that of vulnerability and natural hazards (Fuchs 2009; Giupponi and Biscaro 2015). This change has driven a transformation in the role of the state in terms of responsibility sharing and increased individual responsibilities for mitigation and adaptation (Adger et al. 2013, 2016; Thaler and Levin-Keitel 2016). Additionally, the transformation of responsibility has been encouraged with the implementation of the EU Floods Directive in 2007, such as the introduction of Areas of Potentially Significant Flood Risk (APSFR), ${ }^{1}$ insurance companies, or international risk-averse investors which request a re-thinking of the current financial distribution within hazard management (EC 2007; BMLFUW 2011, 2014; PenningRowsell 2015; Husby et al. 2016). One key question refers to the problem of social justice and injustice within this new policy direction, which plays a central role in the ongoing natural hazard management policy (Collins 2010; Grineski et al. 2012).

Debates on social justices and equity in managing natural hazards and risk became more prominent in the past 10 years (Fielding and Burningham 2005; Colton 2007; Johnson et al. 2007; Walker and Burningham 2011; Thaler and Hartmann 2016). In particular, after Hurricane Katrina in 2005, various publications addressed the question about social and spatial inequality with the aim to understand the impact of natural disasters on low-income households (such as Dixon and Ramutsindela 2006; Elliott and Pais 2006; Bullard and Warf 2009; Walker and Burningham 2011). The research mainly concentrated on the question of which parts of a population (racial/ethnic or low-income individuals) are significantly higher exposed to natural hazards than others (Fielding and Burningham 2005; Colton 2007; Chakraborty et al. 2014; Grineski et al. 2015; Montgomery and Chakraborty 2015; Maldonado et al. 2016). These studies, however, strongly followed the tradition of the 1980s discourse on environmental injustices, where authors argued that environmental injustice is mainly based on the socio-economic status leading to a disproportionate and unequal exposure of individuals (Walker 2012; Harrison 2014). Similar discussion can be found in the discussion within climate justices, whereabouts the focus of

\footnotetext{
${ }^{1}$ The current Austrian flood risk management plan insist the prioritisation of natural hazards mitigation for Areas of Potentially Significant Flood Risk (APSFR) across the country. The designation of the Areas of Potentially Significant Flood Risk (APSFR) is mainly based on four categories: (1) number of people per river mile; (2) infrastructure; (3) industrial complexes with major accidents treats, such as Seveso II industries; and (4) cultural heritage. However, the most important variable was number of people (more than 600 per $\mathrm{km}$ ) which counted $79 \%$ in the overall designation of the APSFR areas (BMLFUW 2015).
}

climate justices lie on unequal distribution of the effects of climate change (Schlosberg and Collins 2014; Schlosberg et al. 2017). In recent years, the research focus concentrated on the challenge of inequality within the post-event phase, such as unequal distribution of federal resources after an event in terms of psychological assistance or financial support (Elliott and Pais 2006; Munoz and Tate 2016).

The latter shifted the debate on distributional consequences (e.g., priorities, resource allocation) of current policy strategies in climate change adaptation (Holland 2017). Local climate adaptation strategies often confront the challenge of prioritisation of resources in adaptation strategies. The main reason is that some social groups are excluded from the planning and implementation process through lack of empowerment (e.g., resources or knowledge). Climate change adaptation strategies are highly technical-oriented with the goal to protect one group, which might include larger negative consequences for others (Thaler and Priest 2014; Holland 2017; Schlosberg et al. 2017). Above all studies from the UK analysed the impact of policy changes within natural hazard management on the society, to demonstrate who gains and who loses from this change (Penning-Rowsell and Pardoe 2012a, b, 2015). This debate again encouraged the question of how funding for natural hazard and risk management should be distributed within a country, and how a respective policy should look like (spatially approach). Hence, future policy might change in either direction, especially if the financial situation of a state is not strong enough to rise the share in investments of state expenditures (Thaler and Priest 2014; Thaler et al. 2016). Besides, a study by Röthlisberger et al. (2017) showed potential approaches for prioritisation in risk reduction and natural hazards management strategies in Switzerland. However, these studies are mainly ex-post oriented with the limitation to show changes from past decisions. In this paper, we provide an ex-ante view of potential impacts by government changes. In particular, to show the potential consequences and implications for the society.

\section{Social justices in natural hazard management}

The concept of justice has a broad understanding and interpretation (Elster 1992; Mill 2010; Patrick 2014). Basically, justice concerns questions on the allocation of wealth (resources), participation, and recognition across different members of a society (Schlosberg 2007). Various models and methods can be distinguished, which allow for different interpretations. Neoclassic approaches, for example, have a strong focus on fair distribution and allocation within a market system (Thaler and Hartmann 2016). Nevertheless, studies also report on injustice resulting from a combination between socio-economic and cultural injustice (Schlosberg 2007). Cultural factors 
are reflected in discrimination of nationality, sexuality, gender, or/and ethnicity (Fraser 1995), and they are characterised in a cultural domination of one or more groups with the result of not recognising and disrespecting minor groups. Therefore, material unequal distribution reflects income and property ownership of each individual citizen. Unequal economic distribution means barriers to access at labour market, education system, and health care and also unequal access to living space with the effect that marginalised population more often inhabits hazard-prone areas based on socio-economic inequality. To overcome these effects, Honneth (2001) suggested the institutional framework as a key driver in the question of social justice and equity. As a result, social justice can be addressed as a link between 'how, and in what way, individuals recognise on another reciprocally' (ibid: 45), and the rules of distribution (material and cultural) are mirrors of society and their institutions. Additionally, 'rules of distribution cannot simply be derived from the relations of production, but are rather to be seen as the institutional expression of a sociocultural dispositive that determines in what esteem particular activities are held at a specific point in time' (ibid: 54). Conflicts over distribution can be only understood as 'symbolic struggles over the legitimacy of the sociocultural dispositive' (ibid: 54 ). To achieve a fair distribution, the political discussion and especially institutions (formal and informal) have to be changed. Justice in natural hazard and risk management demands more than just a fair socio-economic distribution or recognition of cultural roots (Campbell 2012; May and Morrow 2012; Neal et al. 2014; Zwarteveen and Boelens 2014). Justice also relates to the process by which a certain distribution is selected (procedural justice), but this aspect is not covered by this paper. Instead, the type of justice (and philosophical tradition) discussed in this article will concern questions of allocation and distribution of resources and, further, capital and wealth across different members of society.

The key contribution of this study is to examine the potential impacts of changing the current natural hazard management policy in Austria on distributional effects in showing possible impacts of three philosophical schools (utilitarianism, Rawlsians, libertarianism, see also appendix A). The focus lies on the question of the impact on the distributional effects when following strictly one of the three philosophical schools in natural hazard management. Thus, the main aim is to demonstrate how various directions within the social justice debate potentially affect the national hazard mitigation policy in Austria. Accordingly, we focus on the question of how distributional effects can be organised within the country based on three theoretical schools within the social justice debate. The selected schools focus their key concept and main arguments around distributional effects of new policy concepts and strategies. The key questions surrounding those problems include the following:

- What are the potential impacts of changing national risk mitigation strategies in Austria based on different justice frameworks?

- Which regions would profit from a change in the national risk mitigation strategy towards a more Rawlsians understanding of social justice?

This paper is distinguished in two main sections. The first part focuses on the theoretical discussion of social justices, which provided the analytical framework for our study. In the second part, we present results of our experimental study. The focus is on the question of distributional impacts if the Austrian natural hazard management policy would change for the period 2016-2045.

\section{Data and methods}

The study was conducted in three consecutive steps. The first step was the identification of buildings exposed to snow avalanches and flood hazards (from the year 2012). The actual state of exposure to natural hazards provided the starting point for the experimental analysis of the impacts of different policies. In the second step, we developed a method for considering the different hierarchical units in the impact analysis. On the basis of this framework, the third step included the evaluation of the outcome of each policy for the period 2016-2045.

\section{Assessing natural hazard exposure}

In this paper, assessed hazards included river and torrential flooding in mountain areas as well as snow avalanches. The Austrian legislation foresees the introduction of hazard zones in land use planning to regulate the land use development; these are mandatory mainly for the upper part of the catchments. The method for delimiting hazard zones is regulated by a national legal act (Republic of Austria 1975) and an associated decree (Republic of Austria 1976; compare Holub and Fuchs 2009). Hazard maps are based on a design event with a frequency of 1 in 150 years, and an event occurring more frequent with a return period of 1 in 10 years (ibid.). The underlying magnitude is related to the expected impact pressure and flow height, respectively. In overall, red hazard zones indicate those areas where the permanent utilisation for settlement and traffic purposes is not possible or only possible with extraordinary efforts for mitigation measures. Yellow hazard zones indicate those areas where a permanent utilisation for settlement and traffic purposes is impaired by hazard processes. However, main critique includes (i) that hazard maps show only the actual situation, without taking into account future 
developments, such as process dynamics resulting from climate change (Auer et al. 2007; Keiler et al. 2010; Huggel et al. 2012) as well as (ii) that the focus is on the actual hazard extent in the respective run-out areas (mainly residential areas) and excludes a broader view of the space, e.g. with respect to agricultural land use in the drafting process of hazard maps.

We defined exposed buildings as built structures that are susceptible to mountain hazards. Therefore, we overlaid the national building inventory data with the hazard maps in a geographic information system (GIS) (Fuchs et al. 2015, 2017). The Austrian building and residents inventory was provided by the Federal Ministry of Agriculture, Forestry, Environment, and Water Management. We classified each building by 14 categories based on its main use and calculated the economic value of each building. The economic valuation is conducted by an economic module based on building type as well as average construction costs based on Kranewitter (2002) and Keiler et al. (2006). Further, the construction costs were analysed based on replacement value (Fuchs and McAlpin 2005). The dataset including the buildings, their functionality and values, and their number of residents was delineated from the Austrian residential register. This dataset and the method for processing the data are described in-depth by Fuchs et al. (2015). Each building was overlaid with the hazard maps to know the current exposure in Austria. Furthermore, we aggregated the numbers of exposed and non-exposed buildings for the areal units of local governments. With these numbers, we computed the share of exposed buildings, and the ratio of the average building values of exposed and non-exposed buildings.

\section{Hierarchical units of analysis}

For the exposure analysis, the analysis was done on an objectbased level (individual house in a hazard zone), and the data were aggregated at the required level, depending on the chosen policy scenario.

- The first level refers to the building data. A building object is represented spatially by a point and has the following attributes: the type of functionality, the reconstruction value of the building, and the number of principal residents. Each building object is member of (i) an administrative unit (i.e. of a local government and of a region) and (ii) of a hazard zone.

- The second level refers to the hazard zones in Austria. A hazard zone is represented by a polygon. The different classes of hazard zones (red and yellow zones depending on the process intensities) and overlapping or neighbouring hazard zones are merged into one polygon representing a hazard zone. Therefore, the hazard process type and the process intensities are not differentiated in this study. A hazard zone polygon is member of an administrative unit (of a local government and of a region) and provides the reference unit for the future investigation in our analysis.

- The third level refers to the local administrative unit. The main aggregation and reference unit is the smallest administrative unit at local level, i.e. the area of responsibility of a local government. All financial projects invested in risk prevention at hazard zone level are summed up at local level.

With this topological setting, the analysis was done on an object-based level (individual house in a hazard zone), and the data were aggregated at the required level, depending on the chosen policy scenario.

\section{Implementation of policy scenarios}

The concept of utilitarianism, developed by classical economists, such as John Stuart Mill and Graham Bentham, understands justice and equity as the sum of individual benefits. The aim of utilitarianism is to 'maximise the total potential happiness of society as a whole through the aggregation of individual happiness' (Johnson et al. 2007: 376). Thereby, the focus is on benefits of each individual (Bartel 2002), and consequently, policy discussion should ensure maximal benefit of society ('greatest benefit to the greatest number', Hunold and Young 1998: 84). In natural hazard management, utilitarianism develops criteria which should be chosen to secure the highest risk reduction per unit of resource input. Natural hazard risk management strategies provided to those areas within country, where the benefits offer the greatest gain to the society (Johnson et al. 2007).

Rawls (2005) defined justice as the equal distribution of basic rights and duties within a society. Justices will be defined by the society, who defines a common understanding of what social justice is, as well as which actions insurance the basic needs for each individual within the society. Based on this understanding, Rawls tolerates injustices, if unequal developments in society increase the overall benefit (wealth) of a society. However, if the outcome reflects injustice, individuals will not be punished/discriminated in another aspect. Referring to natural hazard and risk management, an application of Rawls' concept of justice requests to distribute resources to most vulnerable people and objectives (Johnson et al. 2007). Therefore, the key objective is to select risk management strategies not only and inevitably for high-value assets and areas of high-value aggregation (Johnson et al. 2008).

The main focus of liberalism is in general a concept of free market thinking, with a particular focus on competition, availability of full information, equilibrium in market processes, and freedom of individual self-decision (economic freedom, Hayek 1991; Harrison 2014). Key aspects include the availability of full information, which are mainly pre-defined rules 
equally to each individual (Hayek 1991). The allocation of goods and services is based on equilibrium (Pareto) principles. In natural hazard management policy, the strategies are organised and planned by the sum of individual preferences which are based on rational choice decisions (Varian 1975; Harvey 1999; Bowen and Wells 2002). Consequently, there is a limited influence of the public sector on the natural hazard management policies. As a result, the state would be reduced towards providing hazard information to individuals (Thaler and Hartmann 2016), but the individuals have to manage their risk individually, such as through local structural protection measures or insurance (Holub and Fuchs 2009; PenningRowsell 2015). The overlaying and aggregation procedures depend on the respectively policy scenario.

\section{Utilitarianism}

For the first policy scenario (utilitarianism), we conducted the following steps:

1. The hazard maps were overlaid with the building dataset.

2. For each hazard zone, we summed up the reconstruction values of the exposed buildings.

3. Hazard maps with the aggregated exposed building values were sorted in a descending order. This resulted in a priority list for investments by the sum of exposed vales at risk per hazard zone.

4. It was assumed that following the priority list, in each year, the buildings in a specific number of hazard zones would be protected by defence structures. We assumed a total number of 60 projects $^{2}$ per year for a period of 30 years (2016-2045).

5. At the end of the period, the number of new protection schemes invested following the priority list was summed up at local level. A principal assumption in this study is that from now until the end of the reference period, no more houses will be built in exposed areas. Risk reduction measures will be focused on existing exposed assets only. This showed spatial locations where investment in natural hazard management would be distributed in 30 years following this policy.

\section{Rawlsians}

For the second policy scenario (Rawlsians), we conducted the following steps:

\footnotetext{
${ }^{2}$ The Austrian Torrent and Avalanche Control Authority invests between 60 and 70 million $€$ per year in new protection measures (BMF 2016). We assumed that an average cost of 1 mio. $€$ for a project that reduces the hazards in one single hazard zone. The government implemented 60 mitigation strategies per hazard zone per year.
}

1. The hazard maps were overlaid with the buildings dataset.

2. Local governments were classified by their vulnerability. Because there is no dataset for classifying the vulnerability and the coping capacity of the Austrian local governments, respectively, we elaborated simple indicators for a vulnerability classification (PapathomaKöhle et al. 2017). We used more than one indicator to demonstrate challenges and uncertainties within the decision-making process. The first indicator (i) was the share of the number of exposed buildings in comparison to the total number of buildings per local authority (Fuchs et al. 2015). The higher the number of exposed buildings was in relation to the total number of buildings within the local government, the higher was the vulnerability. As a second indicator, we selected the share of the sum of exposed building values to the total sum of monetary building values (ii) for each local government (Fuchs et al. 2017). The third indicator was based on the average monetary value of the exposed buildings compared to the average monetary value of all buildings in each local government (iii). A value $>1$ means that exposed buildings are more costly than the average of all buildings in the local government. A value $<1$ means that the exposed buildings are less worth than the average of the total building stock in the local authority. The highest ranking in terms of vulnerability had the local government with the lowest value for this indicator. It is assumed that local government where the exposed buildings have a lower monetary value than the average are more vulnerable than others. Hence, this indicator represents an important factor to classify social vulnerability of each local government (Cutter et al. 2003). The local government were classified and ranked by each of these three indicators in a descending order.

3. Classification of the vulnerability of Austrian local governments for the Rawlsians policy is depending on how we define vulnerability. In this paper, we distinguish between three different possibilities: option a, classification based on the share between the number of exposed buildings and the total number of buildings; option $b$, classification based on the sum of exposed building values to the total sum of monetary building values; and option c, classification based on the mean monetary value of the exposed buildings in comparison to the mean monetary value of all buildings in the respective local authority.

4. As for the utilitarianism approach, we assumed that 60 projects for natural hazard risk reduction would be financed per year and invested accordingly to the priority list based on step 2.

5. At the end of the period, the investments following the priority list of vulnerable local governments were 
summed up at local level. This shows the distributional effects in the 30 years period.

\section{Liberalism}

For the third policy scenario (liberalism), we assume that the Austrian natural hazards system change towards a selforiented risk management policy; including no public funding from the national government. The citizens living in the hazard-prone areas have to organise their individual protection scheme. For the third policy scenario (Liberalism), we conducted the following steps:

1. The hazard maps were overlaid with the buildings dataset.

2. We elaborated a map of the exposed building values, aggregated at the level of the local governments. This map - together with the hazard maps - should provide the information of the relevance of natural hazards for the public and for stakeholders in the economy.

3. Evaluation of distribution of hazard maps in Austria.

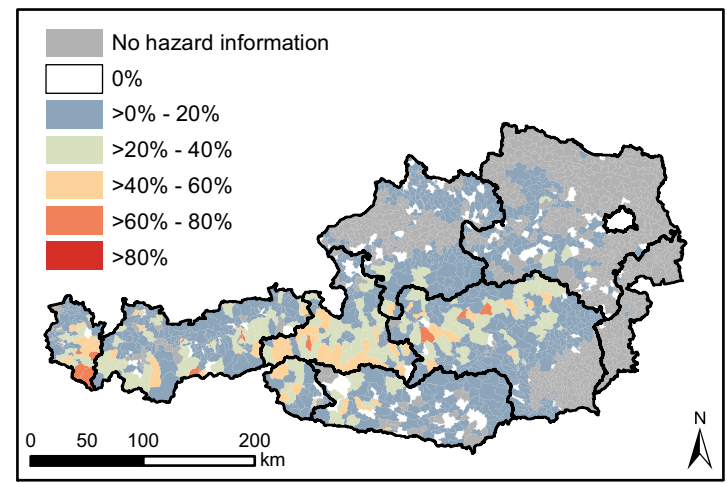

a) share of exposed buildings

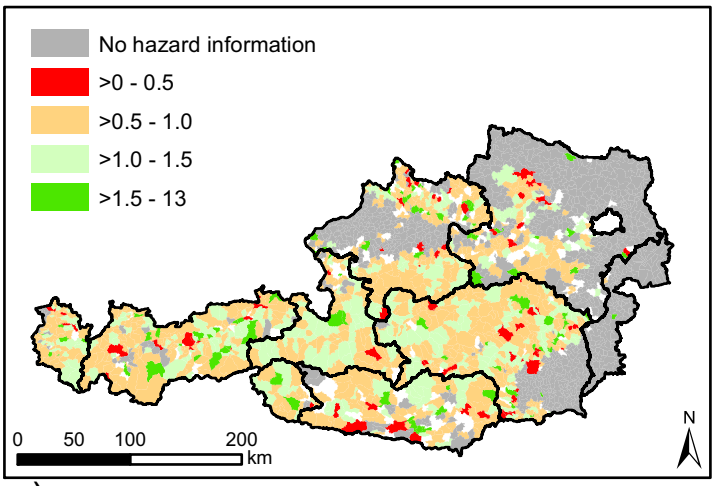

C) ratio of exposed to non-exposed average building values

Fig. 1 The actual state of exposure to mountain hazards and the starting point of the experimental study for the policy impact analysis. a The share of exposed buildings to the total number of buildings in the administrative units of the local governments in Austria. b The share of the exposed building values to the total building values. The highest shares are found in the central and western parts of the country (especially in the federal

\section{Results}

\section{Current situation in the Austrian natural hazards management}

Figure 1 provides information on the monetary values exposed to mountain hazards. The datasets of exposed buildings, monetary values, and residents provided the input for the analyses of distributional effects. The highest monetary values of buildings exposed to mountain hazards - except from a few outliers - can be found among touristic hotspots in Austria, mainly in the Federal states of Salzburg and Tyrol, where many tourist infrastructure in the various skiing areas can be found in hazard-prone areas (Fuchs et al. 2015). The starting point for the model experiment is shown in Fig. 1. In overall, out of a total of 2,399,500 buildings, 120,682 buildings are exposed to mountain hazards within 9978 hazard zones distributed across the nine Federal States. Based on the topography and the characteristic geomorphic processes acting on the land surface, the eastern part of Austria shows a low number of hazard zones defined under the degree of hazard zoning (Republic of Austria 1976) compared to the western part.

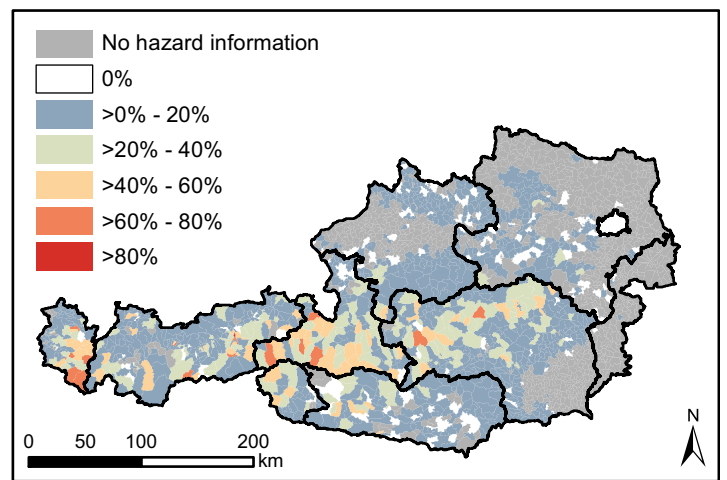

b) share of exposed building values

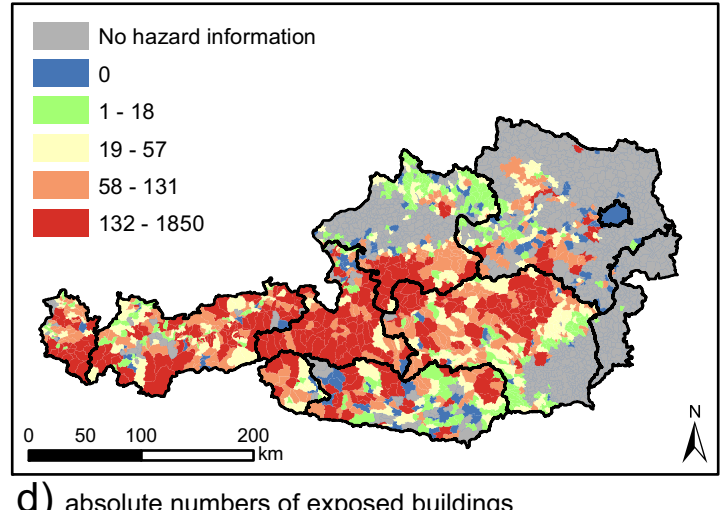

d) absolute numbers of exposed buildings

states Salzburg, Tyrol, and Vorarlberg). c The spatial distribution of the ratio of average building values. Local governments with an average building value of exposed buildings less than the average building value within the areal unit are preferably located in rural and remote areas. In $\mathbf{d}$, the absolute numbers of exposed buildings are shown (quantiles) 


\section{Spatial distribution of funding under a utilitarianism policy framework}

The implication of the introduction of a strict utilitarianism policy approach within the Austrian natural hazard management system would have large impacts on the current funding distribution in Austria. The system would look like the English flood risk management policy (Johnson et al. 2007; Thaler and Hartmann 2016). In Fig. 2, the spatial and temporal analysis of the distribution of funding for the Austrian mountain hazards policy is presented. Between 2016 and 2045, the utilitarianism approach would allow investments into 1800 projects to reduce future impacts of hazard events. At the end of the period, 83,848 buildings with 264,285 residents and with roughly 46.7 billion $€$ of building values would have gained from this policy in terms of the implementation of new structural protection measures. The mean stock of assets secured per hazard zone is about 256 million $€$. The range of choice for the Austrian investment projects show that the concentration of funding would be mainly around the touristic hot spots in Austria (federal state of Salzburg and Tyrol) as well as the federal state of Styria, where a large amount of residential and industrial buildings can be found in hazard-prone areas. On the other hand, the federal states of Vorarlberg, Lower and Upper Austria would loose from the new direction within the funding policy. The main reason is the settlement pattern in these federal states, where building pattern are more dispersed in contrast to other federal states in Austria.

Remarkable differences emerged between the different local governments in Austria. Analysing the local level, the main winners of this policy would be local governments in Salzburg and Tyrol, such as (1) Sankt Leonhard im Pitztal (federal state of Tyrol) with 15 projects for the period 20162045, (2) Kapfenberg (federal state of Styria) with 11 projects for the period 2016-2045, (3) Bad Hofgastein (federal state of Salzburg) for 10 projects for the period 2016-2045, and (4) Kappl (federal state of Tyrol) with 10 projects for the same period. Key targets are again the touristic hotspots in Austria, where the tourism sector has the main contribution to the local economy, except of the city of Kapfenberg. The local authority Kapfenberg includes a large amount of residential buildings as well as industry complexes in the hazard-prone areas. Using the relative relationship (number of projects to the total number of hazard zones in the federal state), the main winners would be the Federal State of Salzburg followed by the federal states of Tyrol and Carinthia (see Table 1).

\section{Spatial distribution of funding under a Rawlsians policy framework}

Analysing the distributional effects under the Rawlsians policy estimates different results in dependence on the selection of indicators. In Fig. 2 and Table 1, the potential implications for the Austrian natural hazard policy are presented. Like the utilitarianism policy framework, under the Rawlisians system, the Austrian government would realise 1800 projects across the country within the time period between 2016 and 2045. By the end of this period, in overall under Rawl's investment policy, the government would protect $157,603,155,264$, and 71,547 residents based on the option $a, b$, and c.

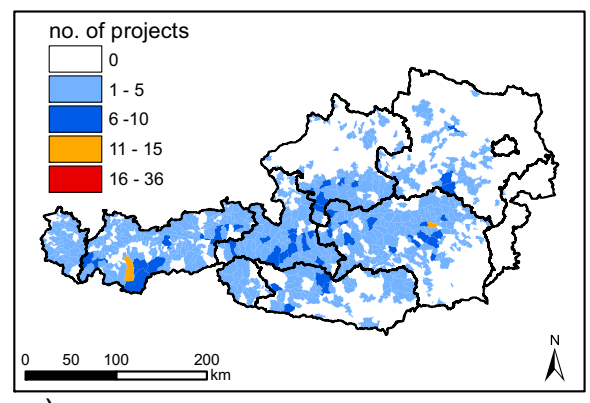

a) Utilitarianism policy framework

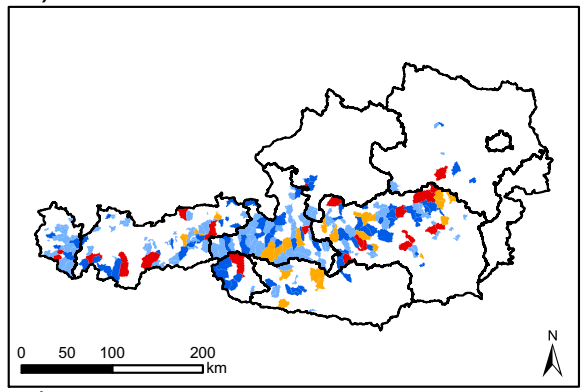

C) Rawlsians policy framework, share of exposed values

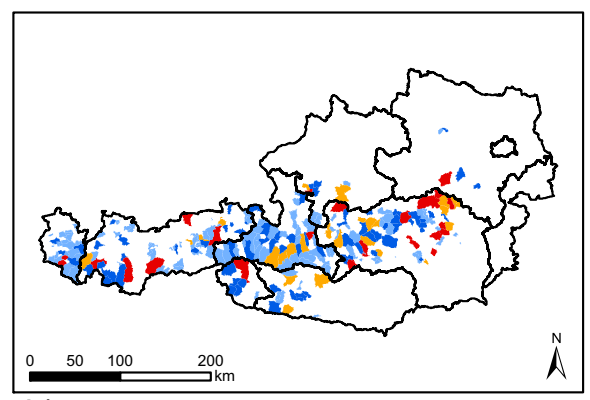

b) Rawlsians policy framework, share of exposed buildings

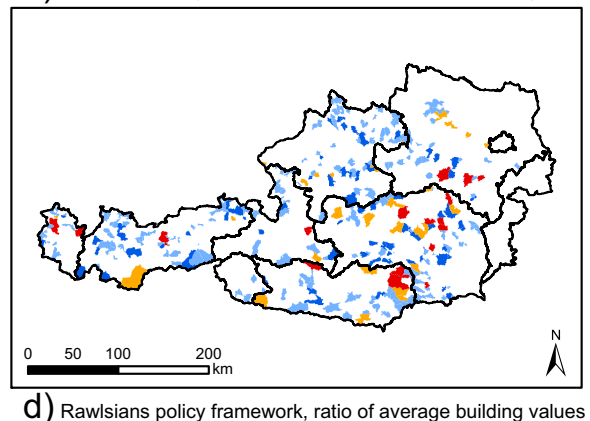

Fig. 2 Sum of projects invested in local governments following a the utilitarianism policy framework for investments in risk reduction measures in the period 2016-2045 in Austria and b, c, d the Rawlsians policy framework in the period 2016-2045 in Austria 
Table 1 Number of projects invested in the communities following the utilitarianism and Rawlsians policy in the period 2016-2045 in Austria, aggregated on regional level

\begin{tabular}{lllll}
\hline & Utilitarianism & Rawlsians & \\
\cline { 3 - 5 } Federal State & $\begin{array}{l}\text { \% No. of projects in } \\
\text { comparison to total } \\
\text { hazard zones in the region }\end{array}$ & $\begin{array}{l}\text { No. of projects in comparison } \\
\text { to total hazard zones in the } \\
\text { region for option (a) [\%] }\end{array}$ & $\begin{array}{l}\text { No. of projects in comparison } \\
\text { to total hazard zones in the } \\
\text { region for option (b) [\%] }\end{array}$ & $\begin{array}{l}\text { No. of projects in comparison } \\
\text { to total hazard zones in the } \\
\text { region for option (c) [\%] }\end{array}$ \\
\hline Burgenland & 12.50 & 13.11 & 14.89 & 27.60 \\
Carinthia & 17.40 & 5.13 & 5.85 & 21.23 \\
Lower Austria & 15.70 & 48.21 & 46.77 & 17.74 \\
Upper Austria & 12.90 & 22.77 & 22.77 & 19.19 \\
Salzburg & 47.80 & 22.57 & 22.81 & 13.89 \\
Styria & 14.00 & 4.44 & 3.19 & 19.38 \\
Tyrol & 23.10 & 0.00 & 0.00 & 0.00 \\
Vienna & 0.00 & 14.92 & 15.03 & 10.59 \\
Vorarlberg & 14.10 & 13.11 & 14.89 & 27.60 \\
\hline
\end{tabular}

In terms of building reconstruction values, the Rawlsians funding policy would protect 28.5, 29.4 respectively 9.5 billion $€$. Following the different policy options, the results show a wide range of spatial distribution within the funding system. In particular, selecting option $\mathrm{c}$ in the distribution of funding would refer mainly to peripheral local governments with a lower economic activity and with a strong focus on agriculture, respectively. Large differences were also found at regional scale in the relative comparison between numbers of projects and total hazard zones (Table 1). Under options a and $b$, the main winners would be the federal states of Lower Austria, Salzburg, and Styria. The numbers and consequently the spatial distribution of profiteers drastically change if option $\mathrm{c}$ is chosen, which would distribute the funding towards the federal states of Burgenland, Tyrol, and Vorarlberg. Such disparities in the results strongly depend on the method chosen and show that these federal states have mainly buildings with a low value at risk in hazard-prone areas.

Looking at the local scale, options a and b showed similar results in terms of the locations benefitting from this policy perspective (Stumm and Fügen in the federal state of Tyrol, St. Anton im Montafon and Innerbraz in the federal state of Vorarlberg). The main reason for this similarity is the large number of detached houses, moreover, tourism dominates areas which results in a high number of exposed hotels. On the other hand, option c would move the funding towards low-income families in hazard-prone areas, such as householders in the local governments Zell am Ziller (federal state of Tyrol), Stolzalpe (federal state of Styria), Mannersdorf am Leithagebirge (federal state of Lower Austria), and St. Jakob im Rosental (federal state of Carinthia). Main winners would be local governments in former industrial areas with structural economic problems or peripheral-rural areas.

\section{Spatial distribution of funding under a liberalism policy framework}

Hazard reduction under a liberalism approach would throughout restructure the Austrian natural hazards system towards a self-oriented risk management policy, including strengthening of self-responsibility (Holub and Fuchs 2009). A first transformation would refer to the implementation of a free market mechanism in terms of compensation, such as the introduction of risk-based insurance systems without public compensation and subvention (Ungern-Sternberg 2004; Fuchs 2009). A second change would affect the realisation of structural measures such as investments in flood-proofing measures instead of large embankments and would transfer the responsibility to individual householders. Consequently, this step would reframe the question of who pays and who gains, because only house owners in hazard-prone zones would have to invest in natural hazard management (Fig. 3). A third change would refer to the provision of information. Hayek (1991), for example, had foreseen the availability and provision of full information as the central characteristic for individual decision behaviour. This means that hazard information has to be very transparent and has to show the individual risk at each location (at individual building level) within the country (Penning-Rowsell 2015). In Austria, for example, such policy would require the design of local-scale hazard and object-specific risk maps. So far, this kind of information is partly available for the country. Nevertheless, various federal states in the eastern part of Austria show a lack of realisation of localscale hazard maps providing the basis for elaborating risk maps (see also appendix B). The challenge might be that the public administration cannot ensure the necessary information for the individuals. 
Fig. 3 Reconstruction values of buildings exposed to mountain hazards in Austria

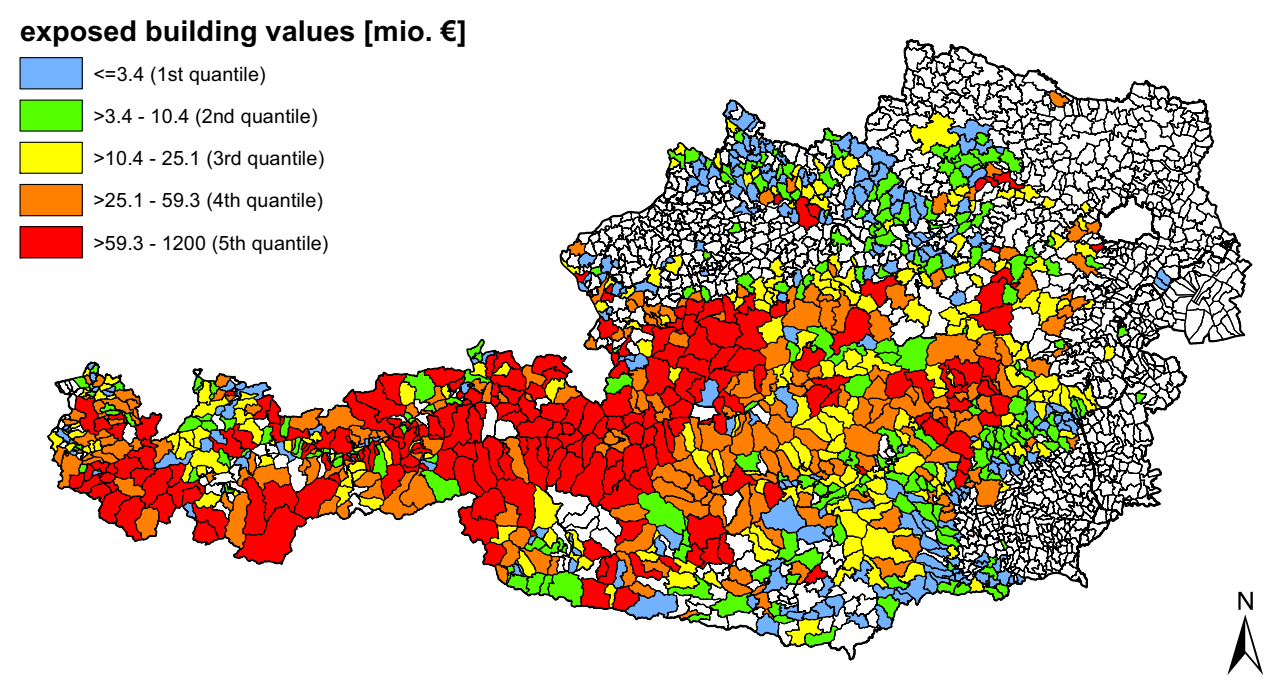

\section{Discussion}

\section{Implications of different national risk mitigation strategies}

In overall, the existing Austrian system of natural hazard and risk management ensures a high level of protection which is equally distributed within the country (Thaler and Hartmann 2016). Nevertheless, the analyses and the debate of the distributional consequences were largely ignored in the current policy, such as in many other countries (Penning-Rowsell and Pardoe 2015). However, in the past years, we observe a first change in the Austrian natural hazard management system, which is mainly based on various interests and external developments, such as the implementation of EU legislation (EC 2007), an increase of exposed buildings within hazardprone areas in some regions of the country (Fuchs et al. 2015, 2017) and economic and financial crises with the consequence of a change within the current spatial distribution on subsidies for natural hazard mitigation. This paper debated and showed the potential implications if the national government would shift the current system towards a more risk-based and vulnerability-based policy, respectively. Such a shift would have large implications for the different householders (positively and negatively depending on the new policy direction). The access to state-provided funding for natural hazard management under a utilitarianism framework would implicate that economic attractive local governments, especially in the tourism hotspots of Austria, would again gain mainly from this policy direction. The resulting governmental focus on high building values in hazard-prone areas would be on one side understandable; on the other hand, the government would encourage the increase of potential losses (Fuchs et al. 2015, 2017). This would generate a situation of moral hazard within the society, because the Austrian policy so far is based on costbenefit analysis when structural mitigation is implemented, which results in securing clusters of high values by structural protection measures (Tarlock 2012). Rawlsians justices as fairness funding policy would instead focus the distribution towards the most vulnerable groups within the society (Cutter et al. 2003; Johnson et al. 2007; Thaler and Hartmann 2016). A central question remains who are the most vulnerable within a society (Cutter 2003; Wisner et al. 2004; Fuchs et al. 2007). In general, focussing on the average building value (option c average monetary value of the exposed buildings), householders with low building values would gain mainly from the new policy direction. The outcome demonstrates that peripheral local governments would benefit disproportionately from new structural protection measures. Such a governmental activity would protect householders who are often socially excluded and have a lack of opportunity to protect themselves (Jacobs 1961; Sen 2010; Lejano and Funderburg 2016). However, if the Austrian government would choose option a (number of exposed buildings) or b (sum of the exposed building values) of the Rawlsian approach, the results provide a different picture. The public authorities would be able to provide protection schemes for higher building values and would secure similar local governments like the utilitarianism, which contradicts the original idea of Rawls to provide a concept of social justices as an alternative to the ideas from Graham Bentham and John Stuart Mill (Lyons 1972; Zerbe and Plotnick 1988). The main reason is that within options a and $\mathrm{b}$, the local governments allowed in the past high-value buildings to be constructed in hazard-prone areas in contrast to option c, where high-value buildings, such as hotels or commercial buildings, were built outside the hazard zones. Consequently, this policy direction would encourage the 
public administration to ignore their own failure in natural hazards management (Jongman et al. 2012, 2014; Fuchs et al. 2017; Röthlisberger et al. 2017). Lastly, the implementation of a liberalism understanding within the Austrian natural hazard management policy would be the most radical shift within the society in terms of responsibility (Johnson and Priest 2008; Thaler and Priest 2014; Mostert 2015; Reese and Jacob 2015). The central responsibility within the natural hazard management discourse would be organised by individuals instead of the public administration. The changes would request that the private property owners have to strengthen the individual resilience capacity to response to future natural hazard events, also in terms of collecting information about the risk (Djordjevic et al. 2011; Kuhlicke et al. 2011; Babcicky and Seebauer 2017). The consequences were that main losers would be householders with a high social vulnerability and a low individual capacity to response to natural hazard events (Chakraborty et al. 2014; Montgomery and Chakraborty 2015; Maldonado et al. 2016) or especially tenants without any possibilities for implementing risk reduction measures, while utilitarian and libertarian principles show similar static implications. Although the latter indicate less financial resources from public administration dedicated for mitigation, there is clearly a different dynamic implication. Utilitarian framework would incentivise building on risky places, while the libertarian principle would deter it and possibly alter relative value of properties.

\section{Limitations of the study}

However, the results have to be interpreted under consideration of the main limitations. Firstly, the experiment is based on a static assumption, i.e. the building stock is assumed to be static over the time period, while in reality, it is remarkably dynamic (Fuchs et al. 2013). Future improvements may consider the growing building stock (exposed and non-exposed buildings). With a growing building stock, the indicators and therefore the priority lists may change over time and a monitoring of the development may be required to continuously adapt the policy (e.g. as proposed by Zischg et al. 2013). Furthermore, the hazard zones will change over time because of changes in the flood defence structures or because of climatic changes (e.g. Staffler et al. 2008; Keiler et al. 2010).

\section{Conclusion}

This study examined the different impacts of different social justice traditions might change the spatial distribution of funding for natural hazard protection schemes. This implicates a strong political debate on the question whom to protect, or on differentiating between upstream and downstream local governments or different economic or cultural regions, which raises a central but barely discussed conflict: who (or rather what) should be protected against hazard events with highest priority? Such changes showed not only a transformation within the public administration but also affected the individual behaviour in responding to natural hazard events. Consequently, our key findings showed several implications not only for the national policy on natural hazard management in Austria but also for the discussion on social justices. We found that depending on the selection of philosophical tradition, the winners and losers will remarkably change. For instance, prioritisation of structural protection measures based on utilitarianism would mainly support the tourism hotspots as well as industrial complexes in the mountain areas. The consequences would be that the public administration would acknowledge and encourage constructing new and more high-value buildings in hazard-prone areas. This would result in an increase of potential losses across the country. On the other hand, focus on the most vulnerable groups (based on mean values of buildings) would mainly support local governments in peripheral areas. As such, this policy would mainly support the main losers from a utilitarianism economic thinking. Yet, the number of individuals who gain from this policy would be much lower in comparison to the other potential options. But in the end, the main question is if the selected philosophical traditions used in this paper should be adopted by the Austrian natural hazards management system, or if disaster risk reduction in Austria needs different/additional instruments and supports. Therefore, the selected approach for the future policy requires not only a scientific but also a political debate. In this way, both the requirements of the EU floods directive and the overall aim to decrease vulnerability and increase resilience for the reduction of social exclusion may be considered.

Acknowledgements Open access funding provided by University of Natural Resources and Life Sciences Vienna (BOKU). This project has been funded by the Austrian Climate and Energy Fund project SHARED (project number KR16AC0K13268). The authors kindly acknowledge data provision by the Austrian Federal Ministry of Agriculture, Forestry, Environment, and Water Management. Furthermore, we would like to thank the two anonymous reviewers for their valuable comments and suggestions to an earlier version of this paper.

Open Access This article is distributed under the terms of the Creative Commons Attribution 4.0 International License (http:// creativecommons.org/licenses/by/4.0/), which permits unrestricted use, distribution, and reproduction in any medium, provided you give appropriate credit to the original author(s) and the source, provide a link to the Creative Commons license, and indicate if changes were made.

\section{References}

Adger N, Quinn T, Lorenzoni I, Murphy C (2016) Sharing the pain: perceptions of fairness affect private and public response to hazard. Annals of American Association of Geographers 5:1079-1096. https://doi.org/10.1080/24694452.2016.1182005 
Adger N, Quinn T, Lorenzoni I, Murphy C, Sweeney J (2013) Changing social contracts in climate-change adaptation. Nat Clim Chang 3: 330-333. https://doi.org/10.1038/nclimate1751

Auer I, Böhm R, Jurkovic A, Lipa W, Orlik A, Potzmann R, Schöner W, Ungersböck M, Matulla C, Briffa K, Jones P, Efthymiadis D, Brunetti M, Nanni T, Maugeri M, Mercalli L, Mestre O, Moisselin JM, Begert M, Müller-Westermeier G, Kveton V, Bochnicek O, Stastny P, Lapin M, Szalai S, Szentimrey T, Cegnar T, Dolinar M, Gajic-Capka M, Zaninovic K, Mastorovic Z, Nieplova E (2007) HISTALP - Historical instrumental climatological surface time series of the Greater Alpine Region. Int J Climatol 27:17-46. https:// doi.org/10.1002/joc.1377

Babcicky P, Seebauer S (2017) The two faces of social capital in private flood mitigation: opposing effects on risk perception and response capacity. J Risk Res 20:1017-1037. https://doi.org/10.1080/ 13669877.2016.1147489

Bartel R (2002) Neo-/Liberalismus und öffentliche Finanzen. Das Öffentliche Haushaltswesen Österreich 43:26-45

Blöschl G, Nester T, Komma J, Parajka J, Perdigao RAP (2013) The June 2013 flood in the Upper Danube Basin, and comparisons with the 2002, 1954 and 1899 floods. Hydrol Earth Syst Sci 17:51975212. https://doi.org/10.5194/hess-17-5197-2013

BMF (2016): Bundesfinanzgesetz 2016 und Detaildokumente. https:// service.bmf.gv.at/BUDGET/Budgets/2016/bfg/teilhefte/_start_ teilhefte.htm [last access: 15/08/2016]

BMLFUW (2009): Kosten-Nutzen-Untersuchungen im Schutzwasserbau. Richtlinie. Vienna: Bundesministerium für Land- und Forstwirtschaft, Umwelt und Wasserwirtschaft

BMLFUW (2011): Vorläufige Bewertung des Hochwasserrisikos 2011. Bericht zur Umsetzung in Österreich. Vienna: Bundesministerium für Land- und Forstwirtschaft, Umwelt und Wasserwirtschaft

BMLFUW (2014) Maßnahmenkatalog des Hochwassermanagementplans. Bundesministerium für Land- und Forstwirtschaft, Umwelt und Wasserwirtschaft, Vienna

BMLFUW (2015): Nationaler Hochwasserrisikomanagementplan. RMP 2015. Vienna: Bundesministerium für Land- und Forstwirtschaft, Umwelt und Wasserwirtschaft

Bowen WM, Wells MV (2002) The politics and reality of environmental justice: a history and considerations for public administrators and policy makers. Public Adm Rev 62:688-698. https://doi.org/10. $1111 / 1540-6210.00251$

Bullard RD, Wright B (2009) Race, place, and environmental justice after Hurricane Katrina: struggles to reclaim, rebuild, and revitalize New Orleans and the Gulf coast. Westview Press, Boulder, CO

Campbell T (2012) Theories of justice. Ashgate, Farnham

Chakraborty J, Collins TW, Montgomery MC, Grineski SE (2014) Social and spatial inequities in exposure to flood risk Miami, Florida. Nat Hazard Rev 15:04014006. https://doi.org/10.1061/(ASCE)NH. 1527-6996.0000140

Collins TW (2010) Marginalization, facilitation, and the production of unequal risk: the 2006 Paso Del Norte floods. Antipode 42:258 288. https://doi.org/10.1111/j.1467-8330.2009.00755.x

Colton C (2007) Environmental justice in a landscape of tragedy. Technol Soc 29:173-179. https://doi.org/10.1016/j.techsoc.2007.01.006

Cutter S (2003) The vulnerability of science and the science of vulnerability. Ann Assoc Am Geogr 93:1-12. https://doi.org/10.1111/14678306.93101

Cutter SL, Boruff BJ, Shirley WL (2003) Social vulnerability to environmental hazards. Soc Sci Q 84:242-261. https://doi.org/10.1111/ 1540-6237.8402002

Dixon J, Ramutsindela M (2006) Urban resettlement and environmental justice in Cape Town. Cities 23:129-139. https://doi.org/10.1016/j. cities.2005.08.003

Djordjevic S, Butler D, Gourbesville P, Ole E, Pasche E (2011) New policies to deal with climate change and other drivers impacting on resilience to flooding in urban areas: the CORFU approach.
Environ Sci Pol 14:864-873. https://doi.org/10.1016/j.envsci.2011. 05.008

EC (2007) Directive 2007/60/EC of the European Parliament and of the Council of 23 October 2007 on the assessment and management of flood risks. European Parliament, Brussels

Elliott JR, Pais J (2006) Race, class, and Hurricane Katrina: social differences in human responses to disaster. Soc Sci Res 35:295-321. https://doi.org/10.1016/j.ssresearch.2006.02.003

Elster J (1992) Local justice: how institutions allocate scarce goods and necessary burdens. Russell Sage Foundation, New York

Fielding J, Burningham K (2005) Environmental inequality and flood hazard. Local Environ 10:379-395. https://doi.org/10.1080/ 13549830500160875

Fraser N (1995): From redistribution to recognition? Dilemmas of justice in a 'post-socialist' age. New Left Review I/212

Fuchs S (2009) Susceptibility versus resilience to mountain hazards in Austria - paradigms of vulnerability revisited. Nat Hazards Earth Syst Sci 9:337-352. https://doi.org/10.5194/nhess-9-337-2009

Fuchs S, Heiss K, Hübl J (2007) Towards an empirical vulnerability function for use in debris flow risk assessment. Nat Hazards Earth Syst Sci 7:495-506. https://doi.org/10.5194/nhess-7-495-2007

Fuchs S, Keiler M, Sokratov S, Shnyparkov A (2013) Spatiotemporal dynamics: the need for an innovative approach in mountain hazard risk management. Nat Hazards 68:1217-1241. https://doi.org/10. 1007/s11069-012-0508-7

Fuchs S, Keiler M, Zischg A (2015) A spatiotemporal multi-hazard exposure assessment based on property data. Nat Hazards Earth Syst Sci 15:2127-2142. https://doi.org/10.5194/nhess-15-2127-2015

Fuchs S, McAlpin MC (2005) The net benefit of public expenditures on avalanche defence structure in the municipality of Davos, Switzerland. Nat Hazards Earth Syst Sci 5:319-330. https://doi. org/10.5194/nhess-5-319-2005

Fuchs S, Röthlisberger V, Thaler T, Zischg A, Keiler M (2017) Natural hazard management from a co-evolutionary perspective: exposure and policy response in the European Alps. Ann Am Assoc Geogr 107:382-392. https://doi.org/10.1080/24694452.2016.1235494

Giupponi C, Biscaro C (2015) Vulnerabilities - bibliometric analysis and literature review of evolving concepts. Environ Res Lett 10:123002. https://doi.org/10.1088/1748-9326/10/12/123002

Grineski SE, Collins TW, Chakraborty J, Montgomery MC (2015) Hazardous air pollutants and flooding: a comparative interurban study of environmental injustice. GeoJournal 80:145-158. https:// doi.org/10.1007/s10708-014-9542-1

Grineski SE, Collins TW, Ford P, Fitzgerald R, Aldouri R, VelazquezAngulo G, de Lourdes Romo Aguilar M, Lu D (2012) Climate change and environmental injustice in a bi-national context. Appl Geogr 33:25-35. https://doi.org/10.1016/j.apgeog.2011.05.013

Habersack H, Bürgel J, Kanonier A (2009) FloodRisk II Vertiefung und Vernetzung zukunftsweisender Umsetzungsstrategien zum integrierten Hochwassermanagement, Synthese. Eigenverlag Bundesministerium für Land- und Forstwirtschaft, Umwelt und Wasserwirtschaft, Vienna

Habersack HM, Bürgel J, Petraschek A (2004) Analyse der Hochwasserereignisse vom August 2002-Floodrisk, Synthese. Eigenverlag Bundesministerium für Land- und Forstwirtschaft, Umwelt und Wasserwirtschaft, Vienna

Harrison JL (2014) Neoliberal environmental justice: mainstream ideas of justice in political conflict over agricultural pesticides in the United States. Environmental Politics 23:650-669. https://doi.org/10.1080/ 09644016.2013.877558

Harvey D (1999) The environment of justice. In: Fischer F, Hajer M (eds) Living with nature: environmental politics as cultural discourse. Oxford University Press, Oxford, pp 153-185

Hayek FA (1991) The road to serfdom. Routledge, London 
Holland B (2017) Procedural justice in local climate adaptation: political capabilities and transformational change. Environmental Politics 26: 391-412. https://doi.org/10.1080/09644016.2017.1287625

Holub M, Fuchs S (2009) Mitigating mountain hazards in Austria-legislation, risk transfer, and awareness building. Nat Hazards Earth Syst Sci 9:523-537. https://doi.org/10.5194/nhess-9-523-2009

Honneth A (2001) Invisibility: on the epistemology of 'recognition'. Aristotelian Society Supplementary 75:111-126. https://doi.org/10. 1111/1467-8349.00081

Huggel C, Clague J, Korup O (2012) Is climate change responsible for changing landslide activity in high mountains? Earth Surf Process Landf 37:77-91. https://doi.org/10.1002/esp.2223

Hunold C, Young IM (1998) Justice, democracy, and hazardous siting. Political Studies 46:82-95. https://doi.org/10.1111/1467-9248. 00131

Husby TG, Mechler R, Jongman B (2016) What if the Dutch started worrying about flood risk? Implications for disaster risk reduction. Reg Environ Chang 16:565-574. https://doi.org/10.1007/s10113015-0769-2

Jacobs J (1961) The death and life of great American cities. Random House, New York

Johnson C, Penning-Rowsell E, Parker D (2007) Natural and imposed injustices: the challenges in implementing 'fair' flood risk management policy in England. Geogr J 173:374-390. https://doi.org/10. $1111 / j .1475-4959.2007 .00256 . x$

Johnson C, Priest S (2008) Flood risk management in England: a changing landscape of risk responsibility. Int J Water Resour Dev 24:513525. https://doi.org/10.1080/07900620801923146

Johnson C, Tunstall S, Priest S, McCarthy S, Penning-Rowsell E (2008) Social justice in the context of flood and coastal erosion risk management: a review of policy and practice. Department for Environment, Food \& Rural Affairs, London

Jongman B, Koks EE, Husby TG, Ward PJ (2014) Increasing flood exposure in the Netherlands: implications for risk financing. Nat Hazards Earth Syst Sci 14:1245-1255. https://doi.org/10.5194/ nhess-14-1245-2014

Jongman B, Ward PJ, Aerts JCJH (2012) Global exposure to river and coastal flooding: Long term trends and changes. Glob Environ Chang 22:823-835. https://doi.org/10.1016/j.gloenvcha.2012.07. 004

Keiler M, Knight J, Harrison S (2010) Climate change and geomorphological hazards in the eastern European Alps. Phil Trans R Soc A 368:2461-2479. https://doi.org/10.1098/rsta.2010.0047

Keiler M, Zischg A, Fuchs S (2006) Methoden zur GIS-basierten Erhebung des Schadenspotentials für naturgefahreninduzierte Risiken. In: Strobl J, Roth C (eds) GIS und Sicherheitsmanagement. Wichmann, Heidelberg, pp 118-128

Kranewitter H (2002) Liegenschaftbewertung. Gesco-Publisher, Vienna

Kuhlicke C, Steinführer A, Begg C, Bianchizza C, Bründl M, Buchecker M, De Marchi B, Di Masso Tarditti M, Höppner C, Komac B, Lemkow L, Luther J, McCarthy S, Pellizzoni L, Renn O, Scolobig A, Supramaniam M, Tapsell S, Wachinger G, Walker G, Whittle R, Zorn M, Faulkner H (2011) Perspectives on social capacity building for natural hazards: outlining an emerging field of research and practice in Europe. Environ Sci Pol 14:804-814. https://doi.org/10. 1016/j.envsci.2011.05.001

Lejano RP, Funderburg R (2016) Geographies of risk, the regulatory state, and the ethic of care. Ann Assoc Am Geogr 106:1097-1113. https:// doi.org/10.1080/24694452.2016.1179565

Lyons D (1972) Rawls versus utilitarianism. J Philos 64:535-545. https:// doi.org/10.2307/2025370

Maldonado A, Collins TW, Grineski SE, Chakraborty J (2016) Exposure to flood hazards in Miami and Houston: are Hispanic immigrants at greater risk than other social groups? Int J Environ Res Public Health 17:E775. https://doi.org/10.3390/ijerph13080775
May L, Morrow P (2012) Procedural justice. Ashgate, The library of essays on justice. Farnham

Mill JS (2010) Utilitarianism, liberty and representative government. Wildside Press, Milton Keynes

Montgomery MC, Chakraborty J (2015) Assessing the environmental justice consequences of flood risk: a case study in Miami, Florida. Environ Res Lett 10:095010. https://doi.org/10.1088/1748-9326/10/ $9 / 095010$

Mostert E (2015) Who should do what in environmental management? Twelve principles for allocating responsibilities. Environ Sci Pol 45: 123-131. https://doi.org/10.1016/j.envsci.2014.10.008

Munoz CE, Tate E (2016) Unequal recovery? Federal resource distribution after a Midwest flood disaster. Int J Environ Res Public Health 17:E507. https://doi.org/10.3390/ijerph13050507

Neal MJ, Lukasiewicz A, Syme GJ (2014) Why justice matters in water governance: some ideas for a 'water justice framework'. Water Policy 16:1-18. https://doi.org/10.2166/wp.2014.109

Papathoma-Köhle M, Gems B, Sturm M, Fuchs S (2017) Matrices, curves and indicators: a review of approaches to assess physical vulnerability to debris flows. Earth Sci Rev 171:272-288. https:/ doi.org/10.1016/j.earscirev.2017.06.007

Patrick MJ (2014) The cycles and spirals of justice in water-allocation decision making. Water Int 39:63-80. https://doi.org/10.1080/ 02508060.2013 .863646

Penning-Rowsell E (2015) Flood insurance in the UK: a critical perspective. WIREs Water 2:601-608. https://doi.org/10.1002/wat2.1104

Penning-Rowsell E, Pardoe J (2012a) Who loses if flood risk is reduced: should we be concerned? Area 44:152-159. https://doi.org/10.1111/ j.1475-4762.2012.01085.x

Penning-Rowsell E, Pardoe J (2012b) Who benefits and who loses from flood risk reduction? Environ Plann C: Gov Policy 30:448-466. https://doi.org/10.1068/c10208

Penning-Rowsell E, Pardoe J (2015) The distributional consequences of future flood risk management in England and Wales. Environ Plann C: Gov Policy 33:1301-1321. https://doi.org/10.1068/c13241

Raschky PA, Weck-Hannemann H (2007) Charity hazard - a real hazard to natural disaster insurance? Environ Hazard 7:321-329. https:// doi.org/10.1016/j.envhaz.2007.09.002

Rawls J (2005) A theory of justice. Harvard University Press, Cambridge

Reese G, Jacob L (2015) Principles of environmental justice and proenvironmental action: a two-step process model of moral anger and responsibility to act. Environ Sci Pol 51:88-94. https://doi.org/ 10.1016/j.envsci.2015.03.011

Republic of Austria (1975) Forstgesetz 1975. Vienna: BGB1. 440/1975

Republic of Austria (1976) Verordnung des Bundesministers für Landund Forstwirtschaft vom 30. Juli 1976 über die Gefahrenzonenpläne. Vienna: BGB1 436/1976

Röthlisberger V, Zischg A, Keiler M (2017): Identifying spatial clusters of flood exposure to support decision making in risk management. Science of Total Environment 598, 593-603. https://doi.org/10. 1016/j.scitotenv.2017.03.216

Schlosberg D (2007) Defining environmental justice: theories, movsements, and nature. Oxford University Press, New York

Schlosberg D, Collins LB (2014) From environmental to climate justice: climate change and the discourse of environmental justice. WIREs Climate Change 5:359-374. https://doi.org/10.1002/wcc.275

Schlosberg D, Collins LB, Niemeyer S (2017) Adaptation policy and community discourse: risk, vulnerability, and just transformation. Environmental Politics 26:413-437. https://doi.org/10.1080/ 09644016.2017 .1287628

Sen A (2010) The idea of justice. Penguin Publisher, London

Sinabell F, Url T (2007) Effizientes Risikomanagement für Naturgefahren am Beispiel von Hochwasser. WIFO Monatsberichte 6(2007):537547

Staffler H, Pollinger R, Zischg A, Mani P (2008) Spatial variability and potential impacts of climate change on flood and debris flow hazard 
zone mapping and implications for risk management. Nat Hazards Earth Syst Sci 8:539-558. https://doi.org/10.5194/nhess-8-5392008

Tarlock DA (2012): Takings, water rights, and climate change. 36 Vermont Law Review 731. http://scholarship.kentlaw.iit.edu/cgi/ viewcontent.cgi? article $=1675 \&$ context $=$ fac_schol. [last accessed 02 Mar 2016]

Thaler T (2014) Developing partnership approaches for flood risk management: implementation of inter-local co-operations in Austria. Water Int 39:1018-1029. https://doi.org/10.1080/02508060.2014. 992720

Thaler T, Hartmann T (2016) Justice and flood risk management: reflecting on different approaches to distribute and allocate flood risk management in Europe. Nat Hazards 83:129-147. https://doi. org/10.1007/s11069-016-2305-1

Thaler T, Levin-Keitel M (2016) Multi-level stakeholder engagement in flood risk management - a question of roles and power: lessons from England. Environ Sci Pol 55:292-301. https://doi.org/10. 1016/j.envsci.2015.04.007

Thaler T, Priest S (2014) Partnership funding in flood risk management: new localism debate and policy in England. Area 46:418-425. https://doi.org/10.1111/area.12135

Thaler T, Priest S, Fuchs S (2016) Evolving interregional co-operation in flood risk management: distances and types of partnership approaches in Austria. Reg Environ Chang 16:841-853. https://doi. org/10.1007/s10113-015-0796-Z
Ungern-Sternberg T (2004) Efficient monopolies - the limits of competition in the European property insurance market. Oxford University Press, Oxford

Varian HR (1975) Distributive justice, welfare economics, and the theory of fairness. Philos Public Aff 4:223-247

Walker G (2012) Environmental justice: concepts, evidence and politics. Routledge, Abingdon

Walker G, Burningham K (2011) Flood risk, vulnerability and environmental justice: evidence and evaluation of inequality in a UK context. Critical Social Policy 31:216-240. https://doi.org/10.1177/ 0261018310396149

Wisner B, Blaikie P, Cannon T, Davis I (2004) At risk: natural hazards, people's vulnerability and disasters. Routledge, London

Zerbe RO, Plotnick RD (1988) Rawlsian difference principles and economic utilitarianism. Soc Justice Res 2:207-222. https://doi.org/10. 1007/BF01054557

Zischg A, Schober S, Sereinig N, Rauter M, Seymann C, Goldschmidt F, Bäk R, Schleicher E (2013) Monitoring the temporal development of natural hazard risks as a basis indicator for climate change adaptation. Nat Hazards 67:1045-1058. https://doi.org/10.1007/s11069011-9927-0

Zwarteveen MZ, Boelens R (2014) Defining, researching and struggling for water justice: some conceptual building blocks for research and action. Water Int 39:143-158. https://doi.org/10.1080/02508060. 2014.891168 